Pakistaniaat : A Journal of Pakistan Studies Vol. 4, No. 1 (2012)

\title{
Review, The State of Islam: Culture and Cold War Politics in Pakistan.
}

\section{Reviewed by David Waterman}

Saadia Toor. The State of Islam: Culture and Cold War Politics in Pakistan. London: Pluto Press, 2011. 252 pages. ISBN-13: 9780745329901.

Saadia Toor is Associate Professor of Sociology at City University of New York, College of Staten Island, and her recent book, The State of Islam: Culture and Cold War Politics in Pakistan, is a welcome addition to contemporary scholarship on Pakistan, precisely because it insists on the importance of cultural elements as part of the political evolution of Pakistan. From the very beginning of the book Toor takes issue with Salman Rushdie's remark that Pakistan is "a place insufficiently imagined," saying instead: "The problem was not ideological confusion, but the active attempts by the Pakistani establishment and its organic intellectuals to marginalize secular and democratic models of the nation-state which they saw as threatening to their interests" (2), the "establishment" being understood as both anti-communist and pro-(radical) Islam (3). After an introductory chapter recalling significant steps in the rise of Muslim nationalism up to and including Partition, The State of Islam follows the major periods since 1947 and the role of progressive voices in opposing abusive policies and programs.

National culture(s) come to the fore immediately after Partition, firstly because not all of India's Muslims left for Pakistan, and secondly because of demands from East Pakistan to elevate the Bengali language to the same status as Urdu - both factors were to destabilize notions of national community. Toor cites Aziz Ahmad, arguing that cultural nationalism takes much longer to achieve than political nationalism (23). Indeed, such cultural divisiveness between the East and West wings of Pakistan would ultimately lead to the secession of East Pakistan, largely as a result, Toor reminds us, of notoriously undemocratic treatment by the Muslim League itself, reflected in the shift toward the right just after Jinnah's death, under Liaquat Ali Khan (33). The One Unit scheme was proposed, ironically, as a political remedy to cultural differences, thus highlighting the role of culture as a political tool in fledgling Pakistan, never forgetting Islam as the "glue" holding the two wings together (Toor 46; 49). 
David Waterman

The following chapter treats literary politics, specifically the progressive versus the nationalist camps, the Progressive Writers Association (tracing its roots to the 1930s in Oxford) versus the anti-communists - among writers and intellectuals, one was obliged to choose sides, what the APPWA Manifesto called "a new phase of the war of independence" $(56 ; 58 ; 60)$. While the nationalists claim to avoid politics in the quest for pure literature, the progressives argue for a political literature which speaks for the people, each accusing the other of disloyalty, a debate which, it must be remembered, took place in a Pakistan still scarred by the recent violence of Partition. Toor refers to many of the progressive writers of the time, most notably Faiz Ahmad Faiz and the allegations of conspiracy surrounding them in the 1950s, at the height of the Cold War (70; 7779).

Chapter Four traces Ayub Khan's “decade of development” (1958-1968) and the political unification of the Left under the auspices of the National Awami Party; Toor suggests that Ayub Khan was "allergic" to such leftist solidarity largely because of its international dimension - recalling of course the situation in Palestine, Algeria or Vietnam (80; 81-82). Military and economic control of society were paramount, but so was the control of cultural institutions, especially the press and the creation of an establishment Writers Guild, not to mention the effort at removing Islam from politics $(86 ; 88 ; 94)$. Opposition to Ayub's regime took more organized form in 1965, after accusations of election-rigging and the loss of the Indo-Pakistan war, giving Zulfiqar Ali Bhutto the opportunity to prepare his accession to power through the creation of the Pakistan People's Party (96). Bhutto's support for Islamic socialism was reaching a wider audience, given the failures of Ayub's anti-communist program and his attempted marginalization of Islam; indeed, Toor argues, it was the communist poet Faiz who inspired the cultural paradigm - Islamic, but uniquely Pakistani - later adopted by Bhutto (110). An admirable idea in theory, yet destroyed in reality by the Pakistani army's attack against East Pakistan in the spring of 1971.

Saadia Toor does not mince her words when assigning blame for the current state of Pakistan: "Every aspect of the Pakistani state, society, politics and culture worth noting today bears the scars of the 11 years of martial law under General Zia ul Haq from 1977 to 1988, Pakistan's longest and most brutal military dictatorship" (117). Zia came to power in the wake of Bhutto's failed promises and mishandling of the military, while links to the Gulf States, especially Saudi Arabia, were reinforced and religious hardliners within Pakistan were appeased rather than challenged. Zia's program of Islamization in all areas of life, public and private, has left traces even today - these are the scars Toor refers to in the above citation. Even Benazir Bhutto would not dare confront the 
Pakistaniaat : A Journal of Pakistan Studies Vol. 4, No. 1 (2012)

religious parties, and the draconian Hudood ordinances and blasphemy laws, for example, are still in place. Although resistance to Zia's policies was dangerous, Toor rightly highlights the Women's Action Forum as one of the associations which gained widespread public support, not only as a political organization but also in terms of cultural production at a time when culture was forcibly aligned with Maududi's agenda (138-139). Zia's regime was able to endure largely as a result of the Soviet invasion of Afghanistan, and the massive influx of American aid; when the Soviets left, the Americans also abruptly dropped their anticommunist ally and its battalions of mujahideen warriors, leaving behind a gunand-drug culture as a souvenir of the war.

The final chapter deals with the situation of women and minorities in the 1990s. Zia's handiwork would not be easily erased, and the aforementioned Kalashnikov culture made for increasing levels of violence within civil society, especially targeting those who were something other than Sunni Muslims (161). Special mention is made of the heroic efforts of the legal activists Asma Jahangir and Hina Jilani in fighting for women's rights and the repeal of the blasphemy laws, issues which continue to occupy activists to this day, not to mention the recurrent problem of honor killings (161). An epilogue brings the reader into the present "security state" of Pakistan (185), dealing primarily with the military's "parasitic" relation to the Pakistani people in terms of land ownership and other corporate ventures (188). As such, Toor is pessimistic about the prospects for Pakistan's democratic future, at least in the short term, and the economic outlook is not much better, as conditions imposed by the IMF and others handicap any real monetary progress $(191 ; 200)$. Thirty pages of detailed endnotes round out the volume, supplying helpful additional information for the reader who might be a little fuzzy on some of the historical details.

The State of Islam ranks among the finest of socio-historical scholarship to be found among the literature today, and will be much appreciated by teachers and researchers, diplomats and politicians alike for its clear, objective presentation of the complex equation of Pakistani cultural politics. I especially appreciated the chapter on Ayub Khan, who is often presented in historical scholarship as a "good dictator," dragging Pakistan kicking and screaming into the modern era; Toor re-places Ayub's regime within its historical context, thus achieving a more nuanced perspective on the "decade of development." Much is to be learned from Saadia Toor's excellent book, perhaps most importantly the mistakes which have been made throughout Pakistan's short history, mistakes which must be analyzed and understood in order to better plan for the future. 